\title{
Decadal glacial lake changes in the Koshi basin, central Himalaya, from 1977 to 2010 , derived from Landsat satellite images
}

Finu SHRESTHA ${ }^{*}$ (D) http://orcid.org/oooo-0oo2-7362-3175; ${ }^{\mathbb{N}}$ e-mail: finu.shrestha@icimod.org

GAO Xiao 2 (D)http://orcid.org/oooo-ooo3-1921-8555; e-mail: 767975074@qq.com

Narendra Raj KHANAL3 iD http://orcid.org/oooo-0oo1-7945-8476; e-mail: nrkhanal.geog@gmail.com

Sudan Bikash MAHARJAN1 (D)http://orcid.org/oooo-0oo2-1307-9200; e-mail: sudan.maharjan@icimod.org

Rajendra Bahadur SHRESTHA1 ${ }^{10}$ http://orcid.org/oooo-ooo1-8748-46o7; e-mail: rajendra.shrestha@icimod.org

WU Li-zong4 (Dhttp://orcid.org/oooo-0oo1-5938-9346; e-mail: wulizong@pric.org.cn

Pradeep Kumar MOOL1 iDhttp://orcid.org/oooo-00o2-2402-7887; e-mail: pkmool.pradeep@gmail.com

Samjwal Ratna BAJRACHARYA1 (D) http://orcid.org/oooo-0oo2-4081-5218;

e-mail: samjwal.bajracharya@icimod.org

\author{
* Corresponding author \\ 1 International Centre for Integrated Mountain Development (ICIMOD), 446oo Kathmandu, Nepal \\ 2 Cold and Arid Regions Environmental and Engineering Research Institute (CAREERI), CAS, Lanzhou 73oooo, China \\ 3 Central Department of Geography, Tribhuvan University, 44600 Kirtipur, Nepal \\ 4 Polar Research Institute of China, Shanghai 200135, China
}

Citation: Shrestha F, Gao X, Khanal NR, et al. (2017) Decadal glacial lake changes in the Koshi basin, central Himalaya, from 1977 to 2010, derived from Landsat satellite images. Journal of Mountain Science 14(10). https://doi.org/10.1007/s11629-016-4230-x

(C) The Author(s) 2017, corrected publication 01/2019

\begin{abstract}
Changes in glacial lakes and the consequences of these changes, particularly on the development of water resources and management of glacial lake outburst flood (GLOF) risk, has become one of the challenges in the sustainable development of high mountain areas in the context of global warming. This paper presents the findings of a study on the distribution of, and area changes in, glacial lakes in the Koshi basin in the central Himalayas. Data on the number of glacial lakes and their area was generated for the years 1977, 1990, 2000, and 2010 using Landsat satellite images. According to the glacial lake inventory in 2010 , there were a total of
\end{abstract}

Received: 29 September 2016 Revised: 06 November 2016 Accepted: 09 June 2017
2168 glacial lakes with a total area of $127.61 \mathrm{~km}^{2}$ and average size of $0.06 \mathrm{~km}^{2}$ in the Koshi basin. Of these, $47 \%$ were moraine dammed lakes, $34.8 \%$ bedrock dammed lakes and $\mathbf{1 7 . 7 \%}$ ice dammed lakes. The number of glacial lakes increased consistently over the study period from 1160 in 1977 to 2168 in 2010, an overall growth rate of $86.9 \%$. The area of glacial lakes also increased from $94.44 \mathrm{~km}^{2}$ in 1977 to $127.61 \mathrm{~km}^{2}$ in 2010, a growth rate of $35.1 \%$. A large number of glacial lakes in the inventory are small in size $(\leq 0.1$ $\mathrm{km}^{2}$ ). End moraine dammed lakes with area greater than $0.1 \mathrm{~km}^{2}$ were selected to analyze the change characteristics of glacial lakes in the basin. The results show that, in 2010, there were 129 lakes greater than $0.1 \mathrm{~km}^{2}$ in area; these lakes had a total area of 42.92 $\mathrm{km}^{2}$ in 1997 , increasing to $63.28 \mathrm{~km}^{2}$ in 2010 . The 
distribution of lakes on the north side of the Himalayas (in China) was three times higher than on the south side of the Himalayas (in Nepal). Comparing the mean growth rate in area for the 33 year study period (1977-2010), the growth rate on the north side was found to be a little slower than that on the south side. A total of 42 glacial lakes with an area greater than $0.2 \mathrm{~km}^{2}$ are rapidly growing between 1977 and 2010 in the Koshi basin, which need to be paid more attention to monitoring in the future and to identify how critical they are in terms of GLOF.

Keywords: Glacial lake; Decadal glacial lake; GLOF; Inventory; Landsat; Koshi basin; Nepal; China

\section{Introduction}

Water mass existing in sufficient amount and extending with a free surface in, under, beside and/or in front of a glacier originated by glacier activities and/or retreating processes of a glacier are called glacial lakes (Campbell 2005). The changing climate is considered as one of the important factors in modifying the glaciated environment. The variation in climate had significant effect on down wasting of glaciers globally (Reynolds 2000; Benn and Lehmkuhl 2000), as a consequence, a number of glacial lakes have formed or found expanding (Bajracharya et al. 2005; Yao et al. 2010). Understanding the response of glacial lakes to climate make it possible to map the long term impact of climate change on water resources. The Himalayas are losing ice mass (Bolch et al. 2012). The hazard due to moraine dammed and/or ice marginal lakes continues to increase (Bajracharya et al. 2005). Glacial lakes, particularly in the central and eastern Himalayas (Nepal and Bhutan), are more numerous and large, and most are growing (Gardelle et al. 2011). The growth in lakes dammed by ice or unstable moraines increases the risk of glacial lake outburst flood (GLOF), threatening lives, property and infrastructure downstream. Although not statistically significant, an increase in GLOF events in the Himalayas has been observed between 1940 and 2000 (Richardson and Reynolds 2000).

Huge loss of property and infrastructure has been caused by GLOFs, for example, the Zhangzangbo (Cirenmaco) in 1981 (Xu 1988; Mool et al. 2001; Khanal and Acharya 2008; Khanal et al. 2015a) and Dig Tsho in 1985 (Ives 1986; Vuichard and Zimmermann 1986, 1987; Bajracharya et al. 2007), which were both in the Koshi basin, drawing the attention of scientists and development planners to the study of glacial lakes and GLOFs in the Himalayas. A total of 18 GLOF events have been reported in the Koshi basin, of which, 13 had local effects less than $40 \mathrm{~km}$ downstream from the lake and five events had impacts further than $40 \mathrm{~km}$ downstream which involved the events of 1964 (Gelhaipuco), 1980 (Nagma Pokhari), 1981 (Zhangzangbo/Cirenmaco), 1985 (Dig Tsho) and 1998 (Tam Pokhari). The events with transboundary effects occurred in 1964 and 1981 in the TAR, China had caused substantial losses in downstream areas in Nepal (Khanal et al. 2015b; Chen et al. 2013; ICIMOD 2011; WECS 1987; Yamada and Sharma 1993).

The first Sino-Nepalese Joint Expedition, with contributions from Canadian scientists, conducted a study on glacial lakes and GLOFs in the Koshi basin and its surrounding area from April to June 1987 (LIGG et al. 1988). The work of this expedition was confined to two sub-basins of the Koshi basin - the Pumqu (Arun) and the Poiqu (Sun Koshi). A glacial lake inventory was prepared using large scale topographic maps (1: 50,00o and 1: 100,000) and aerial photographs, accompanied by field verification and a detailed study of some glacial lakes and GLOF events in the sub-basins. Other inventories have also been conducted in the Koshi basin in Nepal (Mool et al. 2001) and the Koshi basin in the Tibet Autonomous Region (TAR), China (Wu et al. 2005). In 2009, ICIMOD prepared an inventory of glacial lakes for the whole Nepal, including the Koshi basin on the Nepal side, using Landsat images taken in 2005 and 2006 (ICIMOD 2011). A few other attempts have been made to study glacial lakes in some of the subbasins and part of basins both in the China and Nepal covering different periods including the Poiqu/Sun Koshi sub-basin in China (Chen et al. 2007; Wang et al. 2015), Pumqu/Arun sub-basin in China (Che et al. 2014), Rongxer/Tama Koshi subbasin in China and Nepal (Wu et al. 2012), Everest region in Nepal (Bajracharya and Mool 2009; Bajracharya et al. 2011b; Gardelle et al. 2011), and Hinku and Hongu valleys in Nepal (Byers et al. 2013). Similarly, inventories of glacial lakes have been prepared and analyzed for the Chinese 
Himalayas (Wang et al. 2012) and the Third Pole region (Zhang et al. 2015).

In addition, time series mapping and the survey of individual lakes in the Koshi basin, such as Imja Lake (Watanabe et al. 1994; Bajracharya et al. 2009) and Chamlang South Tsho (Lamsal et al. 2014), have been carried out. However, there is a lack of time series information on glacial lakes covering the whole Koshi basin using high resolution satellite images. Therefore, in this study glacial lake inventories were prepared for four different years - 1977, 1990, 2000, and 2010. It provides an overview of the distribution and expansion of glacial lakes along the central Himalayas of the Koshi basin over the last 33 years. This paper also analyses the variation of the different types of surviving glacial lakes in each decades and document the differences in the glacial lake change between north and south side of the Koshi basin from 1977 to 2010. part of the basin in India (1000 persons per $\mathrm{km}^{2}$ ), compared to in the central part in Nepal (276 person $\mathrm{km}^{2}$ ) and the northern part in China (5 persons per $\mathrm{km}^{2}$ ) (Chen et al. 2013). The annual precipitation ranges from $207 \mathrm{~mm}$ in the transHimalayan region to more than $3,000 \mathrm{~mm}$ in the eastern mountains and mid-hills of Nepal. Precipitation patterns in the basin are directly associated with the South Asian monsoon, with about $80 \%$ of annual precipitation falling between June and September. The basin has seven subbasins - the Tamor, Pumqu (Arun), Dudh Koshi, Likhu, Rongxer (Tama Koshi), Poiqu (Sun Koshi) and Indrawati. The Pumqu/Arun, Rongxer/Tama Koshi, and Poiqu/Sun Koshi are transboundary to China and Nepal. The headwaters of all these subbasins lie in glaciated areas within Nepal and China. The total glaciated area in the basin was $2984 \mathrm{~km}^{2}$ with estimated ice reserves of $295 \mathrm{~km}^{3}$ (Bajracharya et al. 2011a). Nearly $8 \%$ of the basin area is covered with snow and ice, including glaciers (Bajracharya et al. 2011a).

\section{Study Area}

The Koshi basin is located in central Himalaya between $25^{\circ} 24^{\prime}$ $7.26^{\prime \prime}$ and $29^{\circ} 08^{\prime} 18.98^{\prime \prime} \mathrm{N}$ latitude and $85^{\circ} 01^{\prime} 36.56^{\prime \prime}$ and $88^{\circ}$ $56^{\prime} 52.77^{\prime \prime}$ E longitude with an area of $61,685 \mathrm{~km}^{2}$. It extends across three countries - India in the south, Nepal in the middle, and China in the north (Figure 1). The basin has an extreme range of altitude, from $29 \mathrm{~m}$ in the lowland plains of India in the south to $8848 \mathrm{~m}$ (Mt. Everest) in the north. It passes through five physiographic zones containing six different biomes and nine ecoregions. Nearly $32.4 \%$ of the total basin area lies in China, 45.1\% in Nepal, and $22.5 \%$ in India (Neupane et al. 2013). The population in the region consists of 15.3 million in 10 ethnic groups, and the number of inhabitants in the region is still increasing. (Chen et al. 2013). The population density is very high in the southern

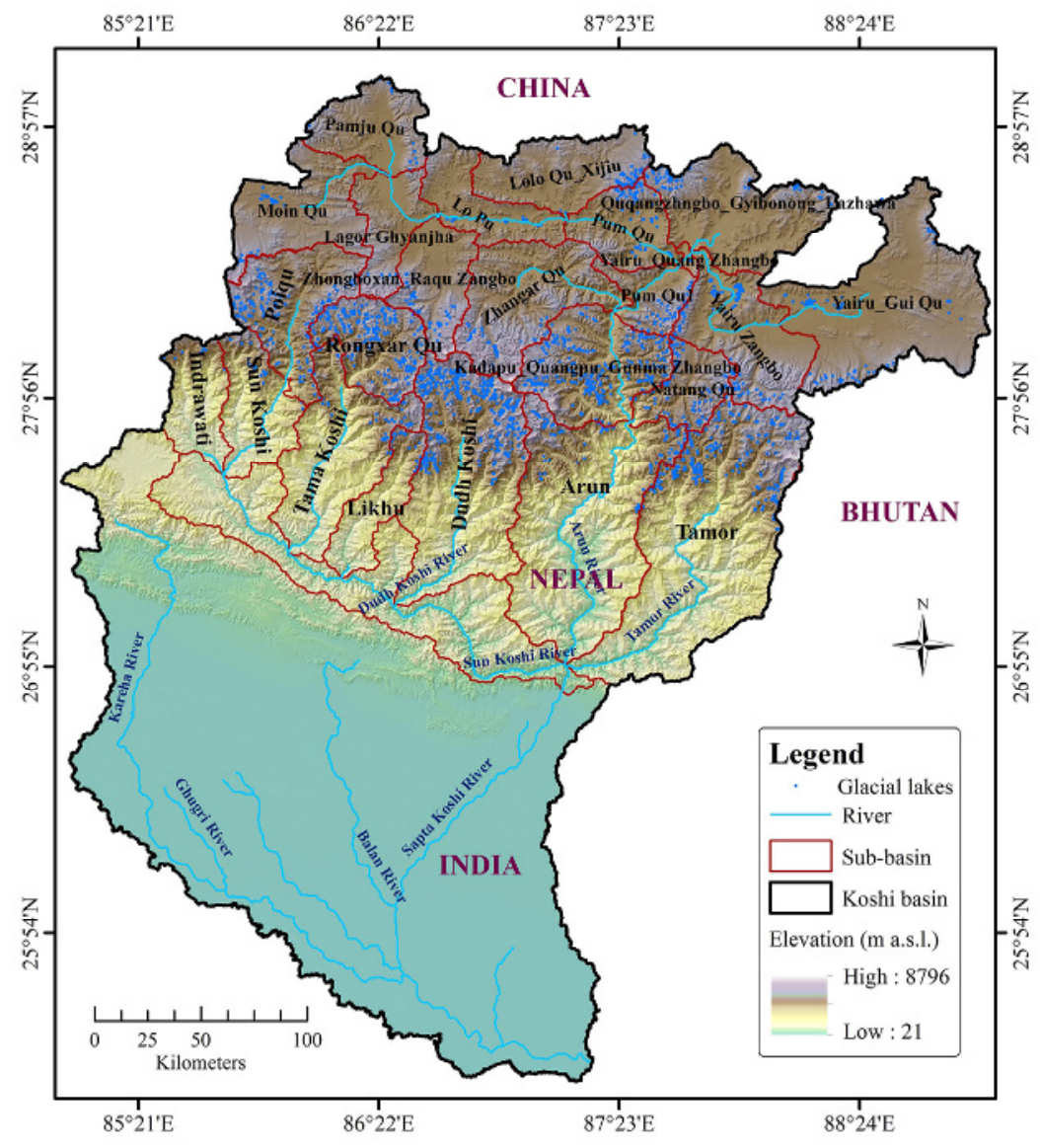

Figure 1 Location and distribution of glacial lakes in the Koshi basin. 


\section{Data and Methodology}

The inventory of glacial lakes was prepared using Landsat satellite images of Multispectral Scanner System (MSS) for 1976-1977, Thematic Mapper (TM) for 1989-1992, and Thematic Mapper/Enhanced Thematic Mapper Plus (TM/ETM+) for 2000-2003 and 2009-2011. These inventories were represented by the years 1977, 1990, 2000, and 2010. These four years were chosen to understand the glacial lakes changes in a decade. The images for 1980 were mostly covered by snow and clouds, hence, images from 1976/1977 were preferred for change analysis. The Landsat images selected for lake delineation were taken between September and November, as there is generally less perennial snow coverage and cloud cover in these months. However, in some cases, when there was cloud obstruction, snow coverage, or mountain shadows, images were acquired for adjacent months.

Different studies have used different methods (automated or semi-automated) for delineating glacial lake outlines (e.g., Frey et al. 2010; Raj et al. 2013; Li and Sheng 2012; Huggel et al. 2002). In this study a semi-automated method was applied using a Normalized Difference Water Index (NDWI) to delineate the glacial lake boundary, as defined in Huggel et al. 2002 (Eq.(1)).

$$
N D W I=\frac{B_{N I R}-B_{\text {blue }}}{B_{\text {NIR }}+B_{\text {blue }}}
$$

where $B_{N I R}$ is the reflectance in near infrared band and $B_{\text {blue }}$ is reflectance in blue band.

NDWI values ranging between -0.60 and -0.85 were applied for the identification of pixels falling into glacial lakes (Frey et al. 2010). As an effect of spectral reflection, some self-shadowed areas were misclassified as lakes. Glacial lakes are sometimes difficult to distinguish from frozen lakes and fresh snow due to differences in surface conditions. Similarly, ice cliffs and walls of supra glacial lakes are also sometimes misclassified as glacial lakes. These misclassified lakes were corrected using visual interpretation in ArcGIS with spectral band combinations of 5, 4, and 2 as RGB by enhancing the visual contrast of the images and overlying them on consecutive images. First, the glacial lake's boundary in 2010 was generated. The previous glacial lake inventory data of ICIMOD prepared for
2009 for the Nepal side of the Koshi basin (ICIMOD 2011) was used to cross-check the data. The missing and misclassified lakes were incorporated manually. For validation and cross checking, the glacial lake boundary was overlaid with high resolution images in Google Earth. If any error was identified, the lake's boundary was further edited using ArcGIS. Finally, a glacial lake inventory for 2010 was prepared (Figure 2).

The glacial lake boundary in 2010 was then overlaid on Landsat images from 2000, 1990, and 1977 and manually edited to generate the glacial lake boundary for the respective years. The glacial lake inventory for 2000 was cross-checked and verified with archived Google Earth images from 2000 to 2002, and the glacial lake inventory prepared using large-scale topographic maps and Landsat ETM images in 2000 for the China side (Wu et al. 2005). Similarly, the 1990 glacial lake inventory was verified using the 1987 glacial lake inventory for parts of the Koshi basin (Pumqu/Arun and Poiqu/Sun Koshi) (LIGG et al. 1988) and large-scale topographic maps and Landsat TM images from 1990 for the China portion (Wu et al. 2005). For the 1977 glacial lake

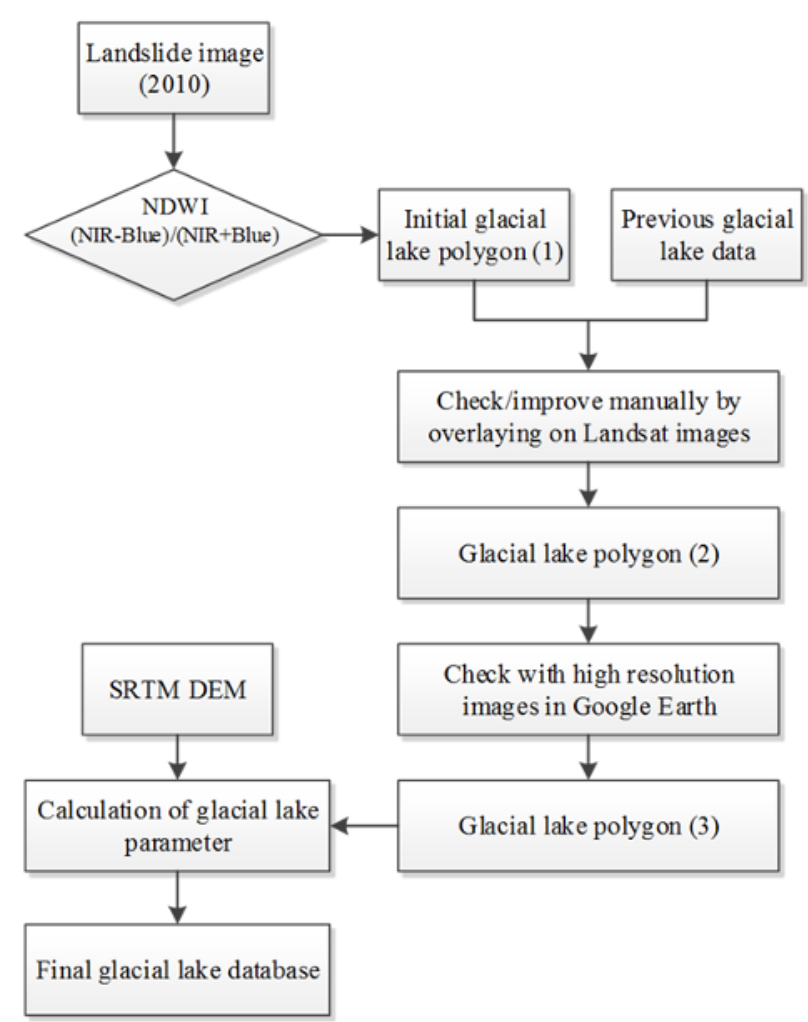

Figure 2 The flowchart showing the processes in the glacial lake inventory. 
inventory, there was no data available for verification.

In this study, we set the minimum threshold value for mapping glacial lakes at $0.003 \mathrm{~km}^{2}$ in TM/ETM+ images; this threshold was also used in mapping glacial lakes based on satellite images by Gardelle et al. (2011). However for MSS images, due to the coarse spatial resolution of the satellite data, the same threshold value for glacial lakes may vary slightly. The glacial lakes boundary was manually digitized at a scale of 1:20,000. Attribute data were assigned to each glacial lake polygon in ArcGIS environment. For each lake, the latitude and longitude of the centre of the lake and area were generated in ArcGIS. Other parameters, such as elevation and slope, were extracted from SRTM DEM. For the identification of the glacial lake (glacial lake ID), the latitude and longitude of the centre of lake were used, the same as in the GLIMS ID developed for glaciers. The ' $G$ ' in the GLIMS ID is replaced by 'GL' to represent the glacial lake (e.g., GLo86923E27899N for Imja Lake). For the classification of glacial lakes in these inventories, the classification scheme used by ICIMOD (2011) was adopted with slight modification in ICIMOD (2011). In this study, we overlaid the mapped glacial lake polygons in the Koshi basin with Google Earth high resolution images and classified them into four major types (moraine dammed, ice dammed, bedrock dammed and other) and seven sub-types of glacial lake. The subtypes are end moraine dammed $\mathrm{M}(\mathrm{e})$, lateral moraine dammed $\mathrm{M}(\mathrm{l})$, and other moraine dammed $\mathrm{M}(\mathrm{o})$ (under the category moraine dammed glacial lake); supraglacial lake I(s) and lakes dammed by tributary valley glaciers $\mathrm{I}(\mathrm{v})$ (under the category of icedammed lake); cirque lake $\mathrm{B}(\mathrm{c})$ and other bedrock dammed $\mathrm{B}(\mathrm{o})$ (under the category of bedrock dammed glacier lake).

\section{Error Estimation}

Glacial lake outlines derived from Landsat images have different levels of accuracy which depends on the resolution of the utilized scenes, the condition at the date of acquisition i.e. seasonal/temporal snow, cloud and shadow. The estimation of uncertainty plays a vital role in determining the accuracy and significance of the results (Bhambri et al. 2011). In this study, we estimated the uncertainty for each glacial lake based on a buffer area with half the sensor resolution (Bolch et al. 2010; Granshaw and Fountain 2006). A buffer area of $30 \mathrm{~m}$ was chosen for MSS and 15m for TM and ETM+ images. The results show that the uncertainty derived from Landsat TM, ETM+ have a smaller uncertainty than those derived from Landsat MSS, however Landsat MSS images remain to be an important resource where most part of the world images are accessible and also deliver some of the only data for the 1970s. The uncertainties estimated for the years 1977, 1990, 2000 and 2010 are $1.1 \%, 0.54 \%, 0.55 \%$ and $0.56 \%$ respectively. The overall uncertainty of the glacial lake from 1977 to 2010 is $1.8 \%$.

\section{Results}

\subsection{Distribution of glacial lakes}

In the 33 year period covered by the study (1977-2010), the area of lakes in the Koshi river basin has increased from $94.44 \mathrm{~km}^{2}$ (116o lakes) in 1977 to $127.61 \mathrm{~km}^{2}$ (2168 lakes) in 2010 (Table 1). Among the 2168 lakes in the inventory, 1213 are located in TAR, China (northern flank of the main Himalayan range) and 955 are located in Nepal (southern flank of the main Himalayan range). Most glacial lakes are located in the Pumqu/Arun sub-basin, followed by the Dudh Koshi, Tamor, Poiqu/Sun Koshi, and Rongxer/Tama Koshi. The number of glacial lakes in the other two sub-basins - the Likhu and Indrawati is 22 and 13, respectively. The average size of glacial lakes in the Koshi basin as a whole is $0.06 \mathrm{~km}^{2}$. The average size of glacial lakes located on the northern slope of the main Himalayas (in China) is nearly double the average size of glacial lakes on the southern slope (in Nepal). Glacial lakes located in the Indrawati

Table 1 Number and area of glacial lakes in different periods

\begin{tabular}{l|l|l|l|l|}
\hline \multirow{2}{*}{ Year } & \multicolumn{2}{|c|}{ Glacial lakes } & \multicolumn{2}{c|}{ Change (\%) } \\
\hline 1977 & 1160 & 94.44 & & \\
\hline 1990 & 2110 & 112.18 & 81.9 & 18.8 \\
\hline 2000 & 2119 & 118.42 & 0.4 & 5.6 \\
\hline $\begin{array}{l}2010 \\
\text { Overall } \\
1977-2010\end{array}$ & 127.61 & 2.3 & 7.8 \\
190 & & 86.9 & 35.1 \\
\hline
\end{tabular}


sub-basin are small with average size of less than $0.02 \mathrm{~km}^{2}$ (Table 2).

Of the total glacial lakes mapped for the 2010 inventory, most (47\%) are moraine dammed lakes followed by bedrock dammed lakes (34.8\%) and ice dammed (17.7\%) lakes. The percentage of moraine dammed and bedrock dammed glacial lakes is comparatively higher on the north side (China) than on the south side (Nepal) of the basin. The percentage of ice dammed lakes is higher on the Nepal side (Table 3). Among the moraine dammed glacial lakes, more than 50\% are other moraine dammed $\mathrm{M}(\mathrm{o})$, followed by $33 \%$ end moraine dammed $\mathrm{M}(\mathrm{e})$. There are comparatively very few cirque type glacial lakes $\mathrm{B}(\mathrm{c})$ compared to the number of other bedrock dammed glacial lakes $\mathrm{B}(\mathrm{o})$ (Table 3). The number of supra-glacial lakes I(s) is higher in the Nepal part of the basin than in the TAR, China part (Table 3). In total, the majority of glacial lakes were other bedrock dammed glacial lakes $\mathrm{B}(\mathrm{o})$ and other moraine dammed lakes $\mathrm{M}(\mathrm{o})$, but the maximum contribution in area was from end moraine dammed lakes $\mathrm{M}(\mathrm{e})$.

A large number of glacial lakes (nearly $91 \%$ ) are small in size $\left(\leq 0.1 \mathrm{~km}^{2}\right)$ with an average size of $0.02 \mathrm{~km}^{2}$ (Table 4). The number of large glacial lakes greater than $1 \mathrm{~km}^{2}$ constitutes less than $1 \%$ of the total number of glacial lakes. Medium sized glacial lakes (with area ranging between $>0.1$ to $\leq 1$ $\mathrm{km}^{2}$ ) comprise nearly $9 \%$ of the total glacial lakes so far mapped for the 2010 inventory.

\subsection{Temporal change in glacial lakes}

The number of glacial lakes increased consistently during the study period, from 1160 in 1977 to 2110 in 1990, 2119 in 2000, and 2168 in 2010 (Table 1). The reason for the greater increase in number of glacial lakes between 1977 and 1990 is the spatial and spectral differences in images used for mapping. Similarly, the glacial lake area increased from $94.44 \mathrm{~km}^{2}$ in 1977 to $127.61 \mathrm{~km}^{2}$ in

Table 2 Number and area of glacial lakes in the Koshi basin (2010)

\begin{tabular}{|l|l|l|l|l|l|l|l|l|l|}
\hline & \multicolumn{4}{|c|}{ Nepal } & \multicolumn{4}{c|}{ China } \\
\cline { 2 - 11 } & No & $\begin{array}{l}\text { Area } \\
\left(\mathrm{km}^{2}\right)\end{array}$ & $\begin{array}{l}\text { Mean size } \\
\left(\mathrm{km}^{2}\right)\end{array}$ & No & $\begin{array}{l}\text { Area } \\
\left(\mathrm{km}^{2}\right)\end{array}$ & $\begin{array}{l}\text { Mean size } \\
\left(\mathrm{km}^{2}\right)\end{array}$ & No & $\begin{array}{l}\text { Area } \\
\left(\mathrm{km}^{2}\right)\end{array}$ & $\begin{array}{l}\text { Mean size } \\
\left(\mathrm{km}^{2}\right)\end{array}$ \\
\hline Tamor & 269 & 8.73 & 0.03 & NA & NA & NA & 269 & 8.73 & 0.03 \\
\hline Pumqu/Arun & 108 & 4.47 & 0.04 & 809 & 61.98 & 0.08 & 917 & 66.45 & 0.07 \\
\hline Dudh Koshi & 480 & 16.90 & 0.04 & NA & NA & NA & 480 & 16.90 & 0.04 \\
\hline Likhu & 22 & 0.39 & 0.02 & NA & NA & NA & 22 & 0.39 & 0.02 \\
\hline Rongxer/Tama Koshi & 44 & 2.93 & 0.07 & 154 & 10.96 & 0.07 & 198 & 13.88 & 0.07 \\
\hline Poiqu/Sun Koshi & 19 & 0.43 & 0.02 & 250 & 20.66 & 0.08 & 269 & 21.09 & 0.08 \\
\hline Indrawati & 13 & 0.16 & 0.01 & NA & NA & NA & 13 & 0.16 & 0.01 \\
\hline Total & 955 & 34.01 & 0.04 & 1213 & 93.60 & 0.08 & 2168 & 127.61 & 0.06 \\
\hline
\end{tabular}

Table 3 Number of glacial lakes in the Koshi basin by type and sub-type (2010)

\begin{tabular}{|c|c|c|c|c|c|c|c|c|c|}
\hline \multirow{2}{*}{ Sub-basin } & \multicolumn{2}{|c|}{ Bedrock dammed } & \multicolumn{2}{|c|}{ Ice dammed } & \multicolumn{3}{|c|}{ Moraine dammed } & \multirow{2}{*}{ Other $(\mathrm{O})$} & \multirow{2}{*}{ Total } \\
\hline & $\mathrm{B}(\mathrm{c})$ & $\mathrm{B}(\mathrm{o})$ & $\mathrm{I}(\mathrm{s})$ & $\mathrm{I}(\mathrm{v})$ & $\mathrm{M}(\mathrm{e})$ & $\mathrm{M}(\mathrm{l})$ & $\mathrm{M}(\mathrm{o})$ & & \\
\hline Nepal & 69 & 175 & 269 & 1 & 130 & 30 & 278 & 3 & 955 \\
\hline Tamor & 35 & 86 & 38 & & 30 & 9 & 69 & 2 & 269 \\
\hline Arun & 16 & 29 & 9 & & 27 & 1 & 26 & & 108 \\
\hline Dudh Koshi & 4 & 33 & 218 & 1 & 64 & 18 & 141 & 1 & 480 \\
\hline Likhu & 3 & 6 & 1 & & 2 & & 10 & & 22 \\
\hline Tama Koshi & 6 & 9 & 3 & & 6 & & 20 & & 44 \\
\hline Sun Koshi & 4 & 6 & & & 1 & 2 & 6 & & 19 \\
\hline Indrawati & 1 & 6 & & & & & 6 & & 13 \\
\hline China & 63 & 448 & 113 & o & 212 & 9 & 364 & 4 & 1213 \\
\hline Pumqu & 47 & 383 & 62 & o & 133 & 3 & 177 & 4 & 809 \\
\hline Rongxar & 9 & 26 & 31 & & 45 & 3 & 136 & & 250 \\
\hline Poiqu & 7 & 39 & 20 & & 34 & 3 & 51 & & 154 \\
\hline Total & 132 & 623 & 382 & 1 & 342 & 39 & 642 & 7 & 2168 \\
\hline
\end{tabular}

Note: $\mathrm{M}(\mathrm{e})$ = end moraine dammed; $\mathrm{M}(\mathrm{l})$ = lateral moraine dammed; $\mathrm{M}(\mathrm{o})=$ other moraine dammed; $\mathrm{I}(\mathrm{s})=$ supraglacial lake; $\mathrm{I}(\mathrm{v})=$ lakes dammed by tributary valley glaciers; $\mathrm{B}(\mathrm{c})=$ cirque lake; $\mathrm{B}(\mathrm{o})=$ other bedrock dammed; $(\mathrm{O})=$ other lake 
2010. This is an overall growth of $86.9 \%$ in terms of the number of glacial lakes and $35.1 \%$ in terms of the area of glacial lakes between 1977 and 2010. The growth in area is comparatively higher than the growth in the number of glacial lakes in the recent decade (2000-2010) compared to previous one (1990-2000). A small portion of the Yaruzangbo sub-basin in the Koshi basin is taken as an example to visualize the changes in glacial lakes in different periods (Figure 3). It was observed that glacier-fed lakes exhibited a continuous growth and accelerated expansion of the lake area, mostly expanded towards the direction of their mother glaciers whereas non glacier-fed lakes showed a moderate and stable trend in area expansion.

Glacial lakes, particularly those that are small in size, are dynamic in nature, appearing and disappearing over time. The percentage of glacial lakes that existed in 1977 and appeared in all four decadal inventories up to 2010 is $95.3 \%$ (Table 5). But, the percentage of glacial lake that was in the
1990 inventory and continued up to 2010 is $81.0 \%$. Similarly, lakes that continued to exist in the 2010 inventory among the lakes mapped for 2000 constituted $85.4 \%$. This shows that the change in the number of glacial lakes increased after 1990. The number of newly formed lakes between 1977 and 1990 is 974 whereas the number of lakes disappeared during the same period is 24 . Although the number of newly-formed lakes decreased significantly in the following decades, the number of newly-formed lakes is still higher

Table 4 Number and area of glacial lakes by size class (2010)

\begin{tabular}{|l|l|l|l|l|l|}
$\begin{array}{c}\text { Lake size } \\
\left(\mathrm{km}^{2}\right)\end{array}$ & \multicolumn{2}{|c|}{ Lake numbers } & \multicolumn{2}{c|}{ Lake area } & $\begin{array}{l}\text { Average } \\
\text { size }\left(\mathrm{km}^{2}\right)\end{array}$ \\
\hline$\leq 0.1$ & 1966 & 90.7 & 37.44 & 29.3 & 0.02 \\
\hline$>0.1-\leq 0.2$ & 84 & 3.9 & 12.05 & 9.4 & 0.14 \\
\hline$>0.2-\leq 1.0$ & 101 & 4.7 & 43.69 & 34.2 & 0.43 \\
\hline$>1.0-\leq 3.0$ & 14 & 0.6 & 20.61 & 16.2 & 1.47 \\
\hline 3 & 3 & 0.1 & 13.82 & 10.8 & 4.61 \\
\hline Total & 2168 & 100.0 & 127.61 & 100.0 & 0.06 \\
\hline
\end{tabular}
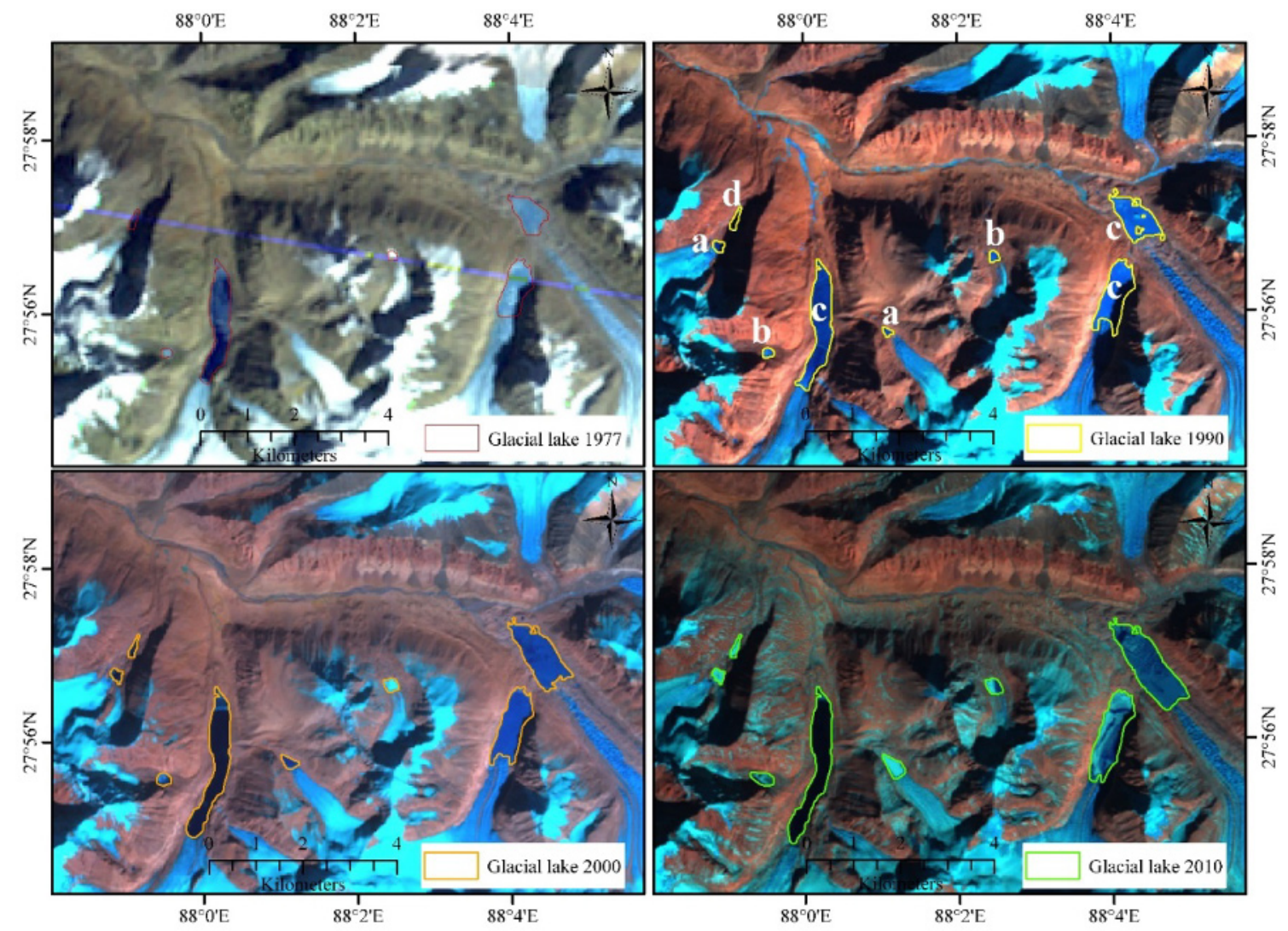

Figure 3 Glacial lakes in four different periods in Yaruzangbo sub-basin, Koshi basin. a) indicates the newly emerging lakes in 1990, b) indicates lakes with increased in size but not directly contact with glacier, c) indicates glacial lakes in contact with glacier and its size expanding towards the direction of mother glacier, and d) indicates glacial lakes without much changes in shape and area. 
than the number of disappeared lakes in the later decades (i.e., after 1990).

The surviving lakes, based on their different types, are presented in Table 6. The study found that the surviving lake areas for $\mathrm{B}(\mathrm{c})$ and $\mathrm{M}(\mathrm{l})$ types are similar in 2010, accounting for $98.64 \%$ and $98.14 \%$ of total lake area in 2010 (i.e., 7.21 $\mathrm{km}^{2}$ for $\mathrm{B}(\mathrm{c})$ and $7.26 \mathrm{~km}^{2}$ for $\mathrm{M}(\mathrm{l})$ ). The surviving $\mathrm{M}(\mathrm{e})$ glacial lakes had a maximum contribution to area of $69.19 \mathrm{~km}^{2}$, which is about $96.70 \%$ of the total $\mathrm{M}(\mathrm{e})$ lake area (i.e., $71.55 \mathrm{~km}^{2}$ ) in 2010 , which is a remarkable increase in lake area over 33 years. The total number of surviving glacial lakes was 1105 (Table 6), which is a lot less than the total number of lakes from 1977 to 2010 (Table 1). In terms of surviving lakes, the difference in total lake area between 1977-1990 and 1990-2000 was quite high. This difference is due to use of the lower resolution images (6om) in 1977 and higher resolution images (30m) in 1990, which led to the major change in the number of glacial lakes from 1977 to 1990 . Table 7 and Figure 4 show the total number and area, and the elevation distribution of different types of newly emerged lakes in 1990. A remarkable change in number was found in $\mathrm{B}(\mathrm{o})$, $\mathrm{M}(\mathrm{o})$, and I(s) type lakes. The total number of $\mathrm{B}(\mathrm{o})$ lakes in 1977 was 401 and in 1990 was 638. Although the lake number from 1977 to 1990 had increased significantly, the area change was not substantial (21.09 km² in 1977 and $23.66 \mathrm{~km}^{2}$ in 2010). Although 239 newly emerged B(o) lakes were counted in number in 1990, the area increase was only $1.95 \mathrm{~km}^{2}$, the mean area increase was $0.008 \mathrm{~km}^{2}$, and the maximum area increase was $0.098 \mathrm{~km}^{2}$. In relation to $\mathrm{M}(\mathrm{o})$ type lakes, the increase in lake number was 346 with an increase in area of $3.04 \mathrm{~km}^{2}$, in mean area of $0.009 \mathrm{~km}^{2}$, and in maximum area of $0.062 \mathrm{~km}^{2}$. Similarly, in I(s) type lakes, 304 newly emerged lakes were counted, with an increase in area of $2.66 \mathrm{~km}^{2}$, in mean area of $0.009 \mathrm{~km}^{2}$, and in maximum area of $0.140 \mathrm{~km}^{2}$. Table 7 shows that most of the newly emerged lakes had a maximum area of less than and equal to $0.1 \mathrm{~km}^{2}$, only $\mathrm{M}(\mathrm{e})$, $\mathrm{I}(\mathrm{s})$, and $\mathrm{O}$ type lakes had an area of greater than $0.1 \mathrm{~km}^{2}$.

\subsection{Rapidly expanding glacial lakes}

Nearly $57 \%$ of glacial lakes that existed in both inventories of 1977 and 2010 had a negative growth rate (Table 8 ). During the same period, nearly $22 \%$ of lakes grew between $1 \%-25 \%$ in area. The percentage of glacial lakes with a growth rate of more than $25 \%$ in area during this period is less than $21 \%$. The study identified 42 rapidly growing lakes that grew by more than $25 \%$ and that are also large in size $\left(>0.2 \mathrm{~km}^{2}\right)$ in the Koshi basin. These

Table 5 Decadal change in the number of glacial lakes

\begin{tabular}{|c|c|c|c|c|c|c|c|c|}
\hline \multirow{2}{*}{ Year } & \multicolumn{6}{|c|}{ Surviving lakes } & \multirow{2}{*}{ Newly formed } & \multirow{2}{*}{ Disappeared } \\
\hline & 1977 & 1990 & 2000 & 2010 & Total number of lakes & $\%$ continued up to 2010 & & \\
\hline 1977 & - & 1134 & 1122 & 1105 & 1160 & $95 \cdot 3$ & & \\
\hline 1990 & - & - & 1756 & 1709 & 2110 & 81.0 & 974 & 24 \\
\hline 2000 & - & - & - & 1808 & 2119 & 85.4 & 342 & 334 \\
\hline 2010 & - & - & - & - & 2168 & & 311 & 261 \\
\hline
\end{tabular}

Table 6 Area and number change in the surviving lakes based on different types

\begin{tabular}{ll|l|l|l|l}
\hline $\begin{array}{l}\text { Lake } \\
\text { type }\end{array}$ & 1977 & 1990 & 2000 & 2010 & Numbers \\
in 2010 \\
B(c) & 6.91 & 6.10 & 7.06 & 7.11 & 121 \\
B(o) & 20.97 & 21.61 & 22.03 & 21.80 & 391 \\
M(e) & 49.43 & 57.43 & 61.80 & 69.19 & 269 \\
M(I) & 7.06 & 7.30 & 7.56 & 7.12 & 27 \\
\hline M(o) & 6.99 & 7.40 & 7.46 & 7.77 & 288 \\
I(s) & 1.45 & 0.07 & 0.09 & 0.06 & 4 \\
\hline O & 0.10 & 0.07 & 0.09 & 0.06 & 5 \\
Total & 92.91 & 100.87 & 106.08 & 113.11 & 1105
\end{tabular}

Notes: $\mathrm{M}(\mathrm{e})$ = end moraine dammed; $\mathrm{M}(\mathrm{l})=$ lateral moraine dammed; $\mathrm{M}(\mathrm{o})$ = other moraine dammed; $\mathrm{I}(\mathrm{s})=$ supraglacial lake; $\mathrm{B}(\mathrm{c})$ = cirque lake; $\mathrm{B}(\mathrm{o})$ = other bedrock dammed; $(\mathrm{O})=$ other lake.
Table 7 Newly emerged lakes in 1990

\begin{tabular}{|l|l|l|l|l|l|}
$\begin{array}{l}\text { Lake } \\
\text { type }\end{array}$ & Number & $\begin{array}{l}\text { Total area Mean area } \\
\left(\mathrm{km}^{2}\right)\end{array}$ & $\begin{array}{l}\text { Max area } \\
\left(\mathrm{km}^{2}\right)\end{array}$ & $\begin{array}{l}\text { Min area } \\
\left(\mathrm{km}^{2}\right)\end{array}$ \\
\hline $\mathrm{B}(\mathrm{c})$ & 10 & 0.06 & 0.006 & 0.010 & 0.003 \\
\hline $\mathrm{B}(\mathrm{o})$ & 239 & 1.95 & 0.008 & 0.098 & 0.003 \\
\hline $\mathrm{M}(\mathrm{e})$ & 63 & 1.28 & 0.020 & 0.309 & 0.004 \\
\hline $\mathrm{M}(\mathrm{I})$ & 11 & 0.10 & 0.009 & 0.014 & 0.005 \\
\hline $\mathrm{M}(\mathrm{o})$ & 346 & 3.04 & 0.009 & 0.062 & 0.003 \\
\hline $\mathrm{I}(\mathrm{s})$ & 304 & 2.66 & 0.009 & 0.140 & 0.003 \\
\hline $\mathrm{O}$ & 1 & 0.36 & 0.362 & 0.362 & 0.362 \\
\hline
\end{tabular}



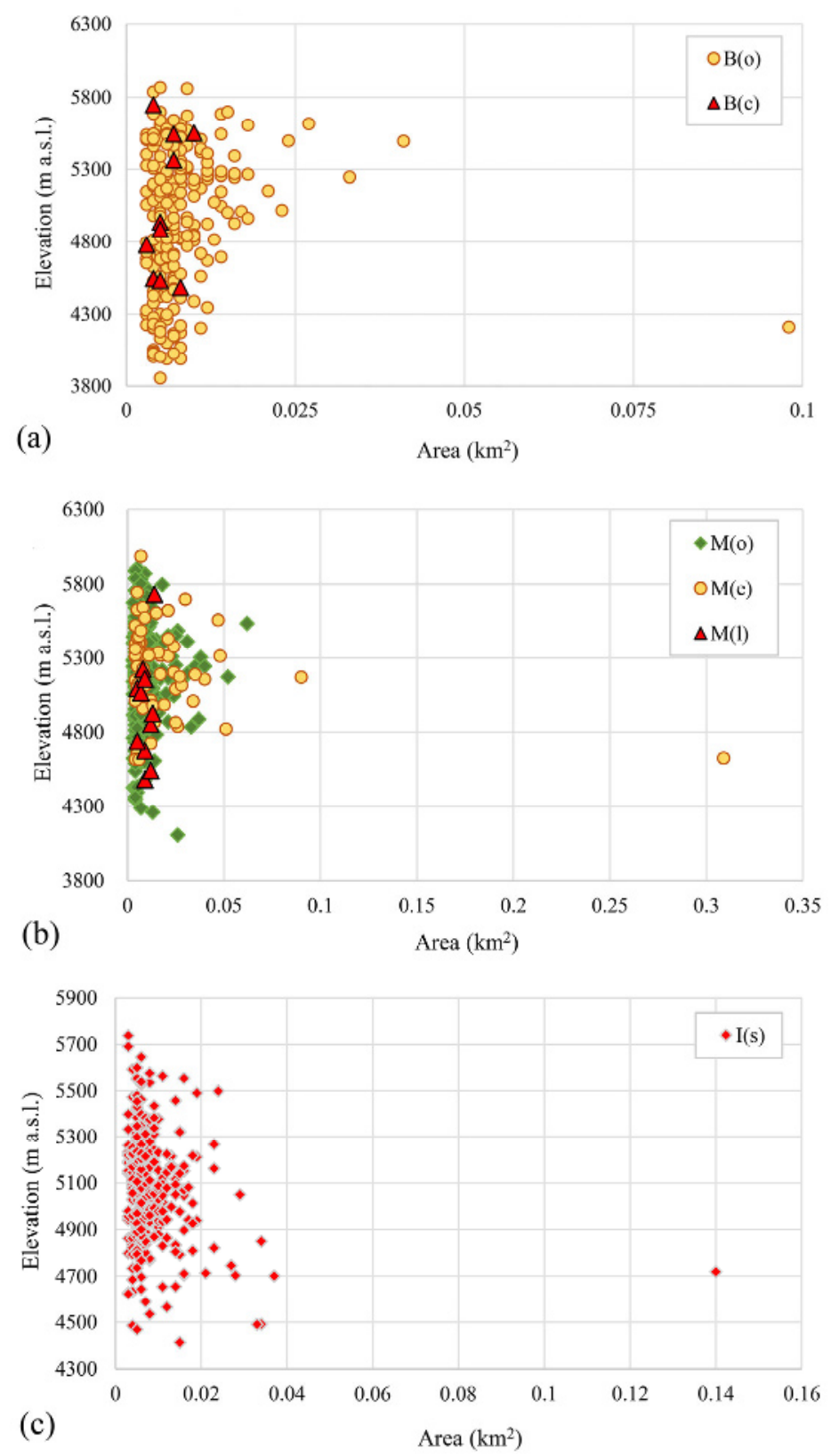

Figure 4 Elevation distribution of different types of newly emerged glacial lakes. (a) bedrock dammed lakes; (b) moraine dammed lakes and (c) supraglacial lakes in 1990.

lakes might have potential for GLOF risk as the volume of water has increased since 1977 and the volume of water is considered as one of the triggers for GLOF (Table 8 and Figure 5). However, further detailed field investigation and modeling based studies of these rapidly growing large lakes are necessary to identify whether they are critical in terms of potential GLOF in the basin.

The majority of glacial lakes in 2010 were small (i.e., $\leq 0.1 \mathrm{~km}^{2}$ in size) (Table 4 ) and showed a negative growth rate over the 33 years of the study and may expand or disappear over time. Lakes greater than $0.1 \mathrm{~km}^{2}$ are considered perpetual and may expand with the retreating of glaciers. From 1977 to 2010, the majority of lakes were end moraine dammed lakes (Table 6). Hence, end moraine dammed lake with area greater than $0.1 \mathrm{~km}^{2}$ were considered for detailed analysis in terms of variation in lake number, area, and length. We divided these lakes into three types, namely: full contact, partial contact, and completely separated, depending on the contact between the glacial lake surface and the glacier, based on 2010 data.

The analysis showed that there were 129 end moraine dammed lakes that were greater than $0.1 \mathrm{~km}^{2}$ in 2010 . The total area of lake was $42.92 \mathrm{~km}^{2}$ in 1977 , increasing to $63.28 \mathrm{~km}^{2}$ in 2010. The distribution of lakes on the north side of the Himalayas (in China) was three times higher than on the south side (in Nepal). On the north side, 96 lakes occupied an area of $49.44 \mathrm{~km}^{2}$, while on the south side 33 occupied an area of $13.85 \mathrm{~km}^{2}$. Among these lakes, 113 lakes changed in area, while 16 lakes remained stable over the 33 years of the study. Since 1977, the area variation in 113 lakes was $0.005 \mathrm{~km}^{2} /$ year of the mean and $0.108 \mathrm{~km}^{2} /$ year of the maximum, while the length variation was $12.06 \mathrm{~m} /$ year of the mean and 101.6 $\mathrm{m} /$ year of the maximum. The average relative rate of change in area was $2.01 \%$ $\left(\mathrm{km}^{2} / \mathrm{km}^{2} /\right.$ year $)$ and the average relative rate of change in length was $1.40 \%$ (m/m/year) (Table 9).

\subsection{Spatial change in the glacial lake}

Among 129 selected glacial lakes, 96 lakes on north side of the Himalayas (in china) had a total area of $49.44 \mathrm{~km}^{2}$, mean area of $0.52 \mathrm{~km}^{2}$, mean length of $1431 \mathrm{~m}$, and mean elevation of $5239 \mathrm{~m}$ a.s.l., while 33 lakes on the south side of the Himalayas (in Nepal) had a total area of $13.85 \mathrm{~km}^{2}$, mean area of $0.42 \mathrm{~km}^{2}$, mean length of $1246 \mathrm{~m}$, and mean elevation of $5025 \mathrm{~m}$ a.s.l. The mean area 
Table 8 Number of glacial lakes according to their growth rate (19772010) and size class (2010)

\begin{tabular}{|l|l|l|l|l|l|l|l|}
\hline \multirow{2}{*}{ Growth } & \multicolumn{8}{|c|}{ Size class $\left(\operatorname{area~in~} \mathrm{km}^{2}\right)$} \\
\hline Negative & 549 & 40 & 39 & 2 & & 630 & 56.7 \\
\hline$\%-25 \%$ & 180 & 28 & 31 & 3 & 1 & 243 & 21.9 \\
\hline $25 \%-50 \%$ & 93 & 3 & 7 & 1 & 2 & 106 & 9.5 \\
\hline $50 \%-75 \%$ & 47 & 1 & 7 & & & 55 & 4.9 \\
\hline $75 \%-100 \%$ & 23 & & 2 & & & 25 & 2.2 \\
\hline$>100 \%$ & 25 & 5 & 15 & & 8 & 53 & 4.8 \\
\hline Total & 917 & 77 & 101 & 6 & 11 & 1112 & 100.0
\end{tabular}

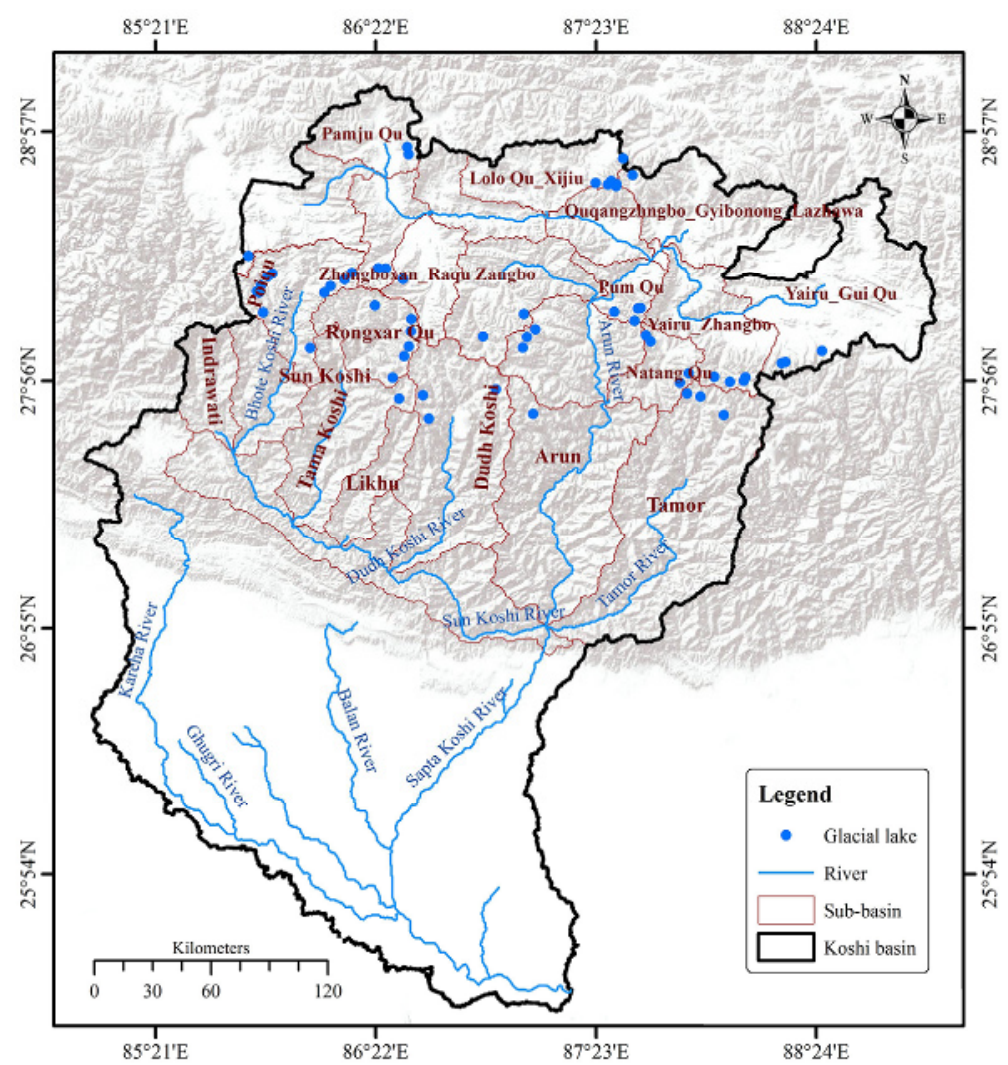

Figure 5 Location of glacial lakes with size class $>0.2 \mathrm{~km}^{2}$ and growth rate $>25 \%$ between 1977 and 2010 .

and elevation of glacial lakes on the north side is higher than on the south side of the Himalayas. In 2010, the elevation for north side ranged from $4300 \mathrm{~m}$ a.s.l. to $5700 \mathrm{~m}$ a.s.l. and for south side from $4300 \mathrm{~m}$ a.s.l. to $5600 \mathrm{~m}$ a.s.l. (Figure 6). Comparing the mean growth rate in area and length for 33 years on the different sides, the growth rate on the north side was a little slower than on the south side. But the mean growth rate in length was higher for the north side than the south side for the years 1990-2000 and 2000-2010, although slower for years 1977-1990 (Table 10).
Figure 7 shows the relationship between lake length variations, distance between the glacier and glacial lake, and the slope of the glacial tongue. It was observed that changing glacial lakes had a high slope at the end of the glacier tongue. Most of the changed glacial lakes were situated between $5^{\circ}-30^{\circ}$ slope (Figure 7). Glacial lakes that were in full contact with the glacier had much faster rate of change than glacial lakes that had partial contact or were completely separated from the glacier. This is because the retreating mother glacier provides space for the glacial lake to expand towards them. The mean rate of change in area for these three types of lakes was $0.014 \mathrm{~km}^{2} /$ year, 0.003 $\mathrm{km}^{2} /$ year, and $0.001 \mathrm{~km}^{2} /$ year, respectively. Similarly, the mean length change rate for these lakes was $26.85 \mathrm{~m} /$ year, $9.76 \mathrm{~m} /$ year, and 4.72 $\mathrm{m} /$ year, respectively (Table 9 ).

\section{Discussions}

\subsection{Size and types of glacial lakes}

A previous study on the types of glacial lakes in the Poiqu sub-basin found a large proportion of moraine dammed lakes (67.3\%) followed by bedrock dammed lakes (18.4\%) (Chen et al. 2007). The proportion of moraine dammed lakes in the Koshi basin as a whole is higher than any other type (Table 3). The percentage of bedrock dammed lakes (47\%) is higher than the percentage of moraine lakes in the Pumqu/Arun (36\%) subbasin. This indicates that there is a large spatial variation in the distribution of glacial lakes by type within the Koshi basin.

The glacial lake inventory of 2010 reported here shows a large number of small glacial lakes with area $\leq 0.1 \mathrm{~km}^{2}$ (i.e., 90.7\%). A study on the size of glacial lakes in the central Himalayas for 2010 also shows a large number and proportion of small lakes (i.e., 70.2\%) (Nie et al 2013). When a 
Table 9 Glacial lake variation in 129 lakes based on contact between the glacier and glacial lake between 1977 and 2010

\begin{tabular}{|c|c|c|c|c|c|c|c|c|c|c|c|}
\hline & \multirow[b]{2}{*}{$\begin{array}{l}\text { Contact } \\
\text { surface }\end{array}$} & \multirow[b]{2}{*}{ No. } & \multirow[b]{2}{*}{$\begin{array}{l}\text { Total } \\
\text { area } \\
\left(\mathrm{km}^{2}\right)\end{array}$} & \multicolumn{4}{|c|}{ Variation in area } & \multicolumn{4}{|c|}{ Variation in length } \\
\hline & & & & $\begin{array}{l}\text { Ave.-C } \\
\left(\mathrm{km}^{2)}\right.\end{array}$ & $\begin{array}{l}\text { Ave.-R } \\
\left(\mathrm{km}^{2} / \text { year }\right)\end{array}$ & $\begin{array}{l}\text { Ave.-RC } \\
\left(\mathrm{km}^{2} / \mathrm{km}^{2}\right)\end{array}$ & $\begin{array}{l}\text { Ave.-RRC } \\
\left(\mathrm{km}^{2} / \mathrm{km}^{2} /\right. \\
\text { year) }\end{array}$ & $\begin{array}{l}\text { Ave.-C } \\
(\mathrm{m})\end{array}$ & $\begin{array}{l}\text { Ave.-R } \\
\text { (m/year) }\end{array}$ & $\begin{array}{l}\text { Ave.-RC } \\
(\mathrm{m} / \mathrm{m})\end{array}$ & $\begin{array}{l}\text { Ave.-RRC } \\
(\mathrm{m} / \mathrm{m} / \text { year) }\end{array}$ \\
\hline \multirow{4}{*}{ 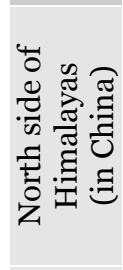 } & \multirow{4}{*}{$\begin{array}{l}\text { Full } \\
\text { contact } \\
\text { Partial } \\
\text { contact } \\
\text { Completely } \\
\text { separated } \\
\text { Total }\end{array}$} & 29 & 28.77 & 0.45 & 0.014 & $114.18 \%$ & $3.46 \%$ & 832.89 & 25.24 & $74.29 \%$ & $2.25 \%$ \\
\hline & & 6 & 2.13 & 0.09 & 0.003 & $38.15 \%$ & $1.16 \%$ & 278.25 & 8.43 & $35 \cdot 31 \%$ & $1.07 \%$ \\
\hline & & 61 & 18.54 & 0.03 & 0.001 & $17.52 \%$ & $0.53 \%$ & 126.82 & 3.84 & $15.86 \%$ & $0.48 \%$ \\
\hline & & 96 & 49.44 & 0.17 & 0.005 & $48.19 \%$ & $1.46 \%$ & 357.01 & 10.82 & $34.39 \%$ & $1.04 \%$ \\
\hline \multirow{4}{*}{ 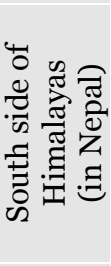 } & \multirow{4}{*}{$\begin{array}{l}\text { Full } \\
\text { contact } \\
\text { contial } \\
\text { Partial } \\
\text { contact } \\
\text { Completely } \\
\text { separated } \\
\text { Total }\end{array}$} & 7 & 6.47 & 0.49 & 0.015 & $123.29 \%$ & $3.74 \%$ & 980.22 & 29.70 & $84.18 \%$ & $2.55 \%$ \\
\hline & & 7 & 3.04 & 0.08 & 0.002 & $123.29 \%$ & $3.74 \%$ & $267 \cdot 58$ & 8.11 & $72.63 \%$ & $2.20 \%$ \\
\hline & & 19 & $4 \cdot 34$ & 0.05 & 0.002 & $68.78 \%$ & $2.08 \%$ & 141.66 & 4.29 & $46.10 \%$ & $1.40 \%$ \\
\hline & & 33 & 13.85 & 0.15 & 0.005 & $89.99 \%$ & $2.73 \%$ & 10.49 & 0.32 & $59.05 \%$ & $1.79 \%$ \\
\hline \multirow{4}{*}{ Total } & $\begin{array}{l}\text { Full } \\
\text { contact }\end{array}$ & 36 & 35.24 & 0.47 & 0.014 & $119.45 \%$ & $3.62 \%$ & 886.15 & 26.85 & $78.60 \%$ & $2.38 \%$ \\
\hline & $\begin{array}{l}\text { Partial } \\
\text { contact }\end{array}$ & 13 & 5.17 & 0.10 & 0.003 & $96.54 \%$ & $2.93 \%$ & 322.05 & 9.76 & $65.47 \%$ & $1.98 \%$ \\
\hline & $\begin{array}{l}\text { Completely } \\
\text { separated }\end{array}$ & 80 & 22.88 & 0.04 & 0.001 & $35.73 \%$ & $1.08 \%$ & 155.63 & 4.72 & $27.69 \%$ & $0.84 \%$ \\
\hline & Total & 129 & 63.28 & 0.18 & 0.005 & $66.44 \%$ & $2.01 \%$ & 398.10 & 12.06 & $46.15 \%$ & $1.40 \%$ \\
\hline
\end{tabular}

Notes: Ave. $-\mathrm{C}=$ Average change; Ave.- $\mathrm{R}=$ Average rate of change; Ave.-RC =Average relative change; Ave. $-\mathrm{RRC}=$ Average relative rate of change
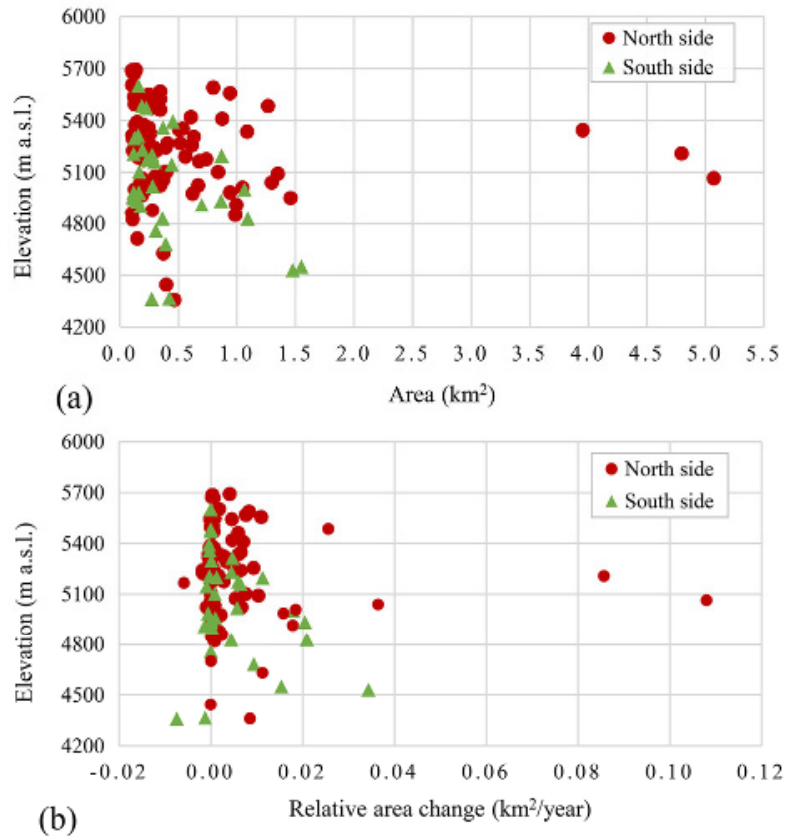

Figure 6 Elevation distribution of glacial lakes (a) and the relationship between elevation and relative area change (b) on the north (in China) and south (in Nepal) sides of the Himalayas.

glacial lake area is less than and equal to $0.1 \mathrm{~km}^{2}$ in size, the images of Landsat TM/ETM+ have an obvious effect on the identification of glacial lake area (Huggel et al. 2002). So this study selected moraine dammed glacial lakes with an area greater than $0.1 \mathrm{~km}^{2}$ for analysis to determine the characteristics of glacial lake variation, as this size class has the highest contribution in area in the Koshi basin. The study found that over the 33 years of the study period (1977-2010) the total area change in glacial lakes differed between the north and south sides of the Himalayas and the distribution of glacial lakes on the north side (in China) was three times higher than on the south side (in Nepal).

\subsection{Change in glacial lakes}

Time series data on the number of glacial lakes generated during this study shows an increase in the number of glacial lakes between 1977-1990 of $81.9 \%$, between $1990-2000$ of $0.4 \%$, between 2000-2010 of $2.3 \%$, and for the three decades 1977-2010 of $86.9 \%$. Similarly, there was an increase in lake area between $1977-1990$ of $18.8 \%$, between 1990-2000 of 5.6\%, between 2000-2010 of $7.8 \%$, and for the three decades 1977-2010 of $35.1 \%$. The number and area of the glacial lakes had increased comparatively higher between 1977 
Table 10 Glacial lake variation in 129 selected glacial lakes in the Koshi basin in different periods

\begin{tabular}{|c|c|c|c|c|}
\hline Period & Glacial lake change & North side & South side & Total \\
\hline 1977 & Total area of glacial lake $\left(\mathrm{km}^{2}\right)$ & 33.10 & 8.92 & 42.96 \\
\hline \multirow{13}{*}{ 1977-1990 } & Total area of glacial lake $\left(\mathrm{km}^{2}\right)$ & 39.35 & 11.61 & 50.96 \\
\hline & Total area change of glacial lake $\left(\mathrm{km}^{2}\right)$ & $5 \cdot 35$ & 2.69 & 8.05 \\
\hline & Percentage of total area change of glacial lake & $15 \cdot 75 \%$ & $30.19 \%$ & $18.75 \%$ \\
\hline & Number of stable glacial lake & 38 & 9 & 47 \\
\hline & Total area of stable glacial lake $\left(\mathrm{km}^{2}\right)$ & 13.69 & 1.98 & 15.67 \\
\hline & Number of growing glacial lake & 49 & 16 & 65 \\
\hline & Total area of growing glacial lake $\left(\mathrm{km}^{2}\right)$ & 22.81 & 7.14 & 29.95 \\
\hline & Mean area growth rate of glacial lake $\left(\mathrm{km}^{2} /\right.$ year $)$ & 0.009 & 0.013 & 0.011 \\
\hline & Mean length growth rate of glacial lake (m/year) & 20.92 & 28.45 & 24.69 \\
\hline & Number of shrinking glacial lake & 9 & 8 & 17 \\
\hline & Total area of shrinking glacial lake $\left(\mathrm{km}^{2}\right)$ & 3.03 & 2.50 & 5.53 \\
\hline & Mean area shrink rate of glacial lake $\left(\mathrm{km}^{2} /\right.$ year $)$ & 0.004 & 0.002 & 0.003 \\
\hline & Mean length shrink rate of glacial lake (m/year) & 7.17 & 5.86 & 6.52 \\
\hline \multirow{13}{*}{ 1990-2000 } & Total area of glacial lake $\left(\mathrm{km}^{2}\right)$ & 42.98 & 12.72 & $55 \cdot 70$ \\
\hline & Total area change of glacial lake $\left(\mathrm{km}^{2}\right)$ & 3.63 & 1.11 & 4.73 \\
\hline & Percentage of total area change of glacial lake & $9.22 \%$ & $9.52 \%$ & $9.29 \%$ \\
\hline & Number of stable glacial lake & 25 & 10 & 35 \\
\hline & Total area of stable glacial lake $\left(\mathrm{km}^{2}\right)$ & 5.79 & 2.61 & 8.40 \\
\hline & Number of growing glacial lake & 49 & 15 & 64 \\
\hline & Total area of growing glacial lake $\left(\mathrm{km}^{2}\right)$ & 30.90 & 6.96 & 37.86 \\
\hline & Mean area growth rate of glacial lake $\left(\mathrm{km}^{2} /\right.$ year $)$ & 0.008 & 0.009 & 0.008 \\
\hline & Mean length growth rate of glacial lake (m/year) & 19.09 & 17.93 & 18.51 \\
\hline & Number of shrinking glacial lake & 22 & 8 & 30 \\
\hline & Total area of shrinking glacial lake $\left(\mathrm{km}^{2}\right)$ & 6.29 & 3.14 & 9.44 \\
\hline & Mean area shrink rate of glacial lake $\left(\mathrm{km}^{2} /\right.$ year $)$ & 0.002 & 0.003 & 0.002 \\
\hline & Mean length shrink rate of glacial lake (m/year) & 4.30 & 13.05 & 8.67 \\
\hline \multirow{13}{*}{ 2000-2010 } & Total area of glacial lake $\left(\mathrm{km}^{2}\right)$ & 49.44 & 13.85 & 63.28 \\
\hline & Total area change of glacial lake $\left(\mathrm{km}^{2}\right)$ & 6.46 & 1.13 & $7 \cdot 59$ \\
\hline & Percentage of total area change of glacial lake & $15.02 \%$ & $8.91 \%$ & $13.63 \%$ \\
\hline & Number of stable glacial lake & 37 & 11 & 48 \\
\hline & Total area of stable glacial lake $\left(\mathrm{km}^{2}\right)$ & 15.13 & 3.06 & 18.19 \\
\hline & Number of growing glacial lake & 50 & 12 & 62 \\
\hline & Total area of growing glacial lake $\left(\mathrm{km}^{2}\right)$ & 31.05 & 8.42 & 39.47 \\
\hline & Mean area growth rate of glacial lake $\left(\mathrm{km}^{2} /\right.$ year $)$ & 0.013 & 0.011 & 0.012 \\
\hline & Mean length growth rate of glacial lake (m/year) & $34 \cdot 37$ & 24.42 & 29.40 \\
\hline & Number of shrinking glacial lake & 9 & 10 & 19 \\
\hline & Total area of shrinking glacial lake $\left(\mathrm{km}^{2}\right)$ & 3.26 & 3.23 & 6.49 \\
\hline & Mean area shrink rate of glacial lake $\left(\mathrm{km}^{2} /\right.$ year $)$ & 0.001 & 0.001 & 0.001 \\
\hline & Mean length shrink rate of glacial lake (m/year) & 4.26 & 3.53 & 3.90 \\
\hline \multirow{12}{*}{ 1977-2010 } & Total area change of glacial lake $\left(\mathrm{km}^{2}\right)$ & 15.44 & 4.93 & 20.37 \\
\hline & Percentage of total area change of glacial lake & $45 \cdot 41 \%$ & $35.60 \%$ & $47.46 \%$ \\
\hline & Number of stable glacial lake & 12 & 5 & 17 \\
\hline & Total area of stable glacial lake $\left(\mathrm{km}^{2}\right)$ & 3.11 & 0.92 & 4.03 \\
\hline & Number of growing glacial lake & 68 & 17 & 85 \\
\hline & Total area of growing glacial lake $\left(\mathrm{km}^{2}\right)$ & 42.58 & 9.39 & 51.96 \\
\hline & Mean area growth rate of glacial lake $\left(\mathrm{km}^{2} /\right.$ year $)$ & 0.007 & 0.010 & 0.008 \\
\hline & Mean length growth rate of glacial lake (m/year) & 16.92 & 16.74 & 16.83 \\
\hline & Number of shrinking glacial lake & 16 & 11 & 27 \\
\hline & Total area of shrinking glacial lake $\left(\mathrm{km}^{2}\right)$ & 3.75 & 3.54 & 7.29 \\
\hline & Mean area shrink rate of glacial lake $\left(\mathrm{km}^{2} /\right.$ year $)$ & 0.001 & 0.001 & 0.001 \\
\hline & Mean length shrink rate of glacial lake (m/year) & 1.24 & 4.40 & 2.82 \\
\hline
\end{tabular}



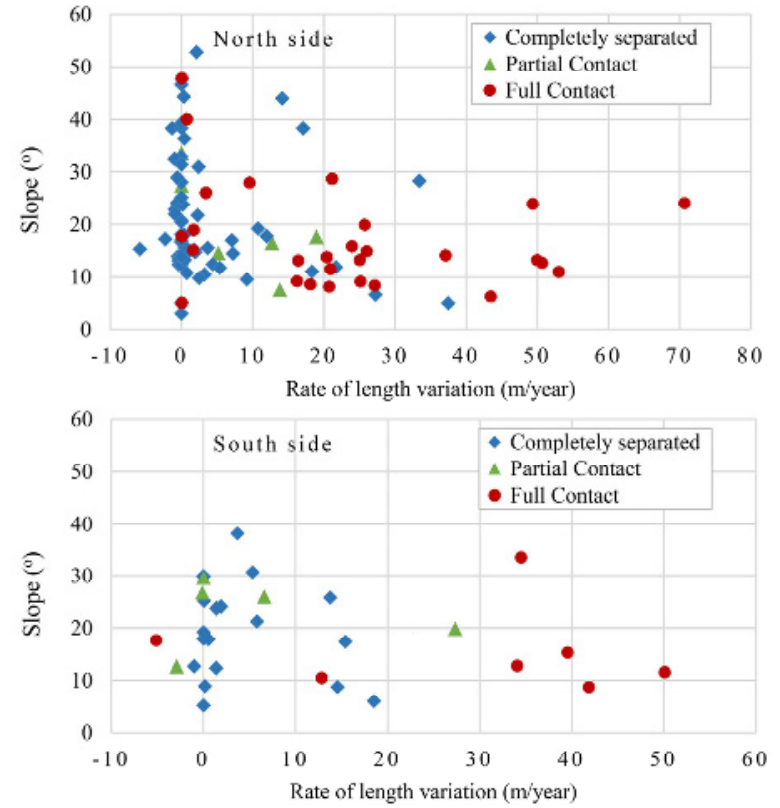

Figure 7 The relationship between lake length variation, distance between glacier and glacial lake, and the slope of the glacial tongue on the north side (up) and the south side (down).

to 1990 than between 1990 to 2000 and 2000 to 2010. There are mainly two reasons: one, the image used in 1977 was of lower resolution (Landsat MSS of $60 \mathrm{~m}$ ) and the rest for other decades including 1990 was of higher resolution (Landsat TM/ETM+ of $30 \mathrm{~m})$. Many small lakes were mapped from the high resolution images, which made the number and area of glacial lakes higher than in 1977. Secondly, the rapid melting and decrease of glacier area has resulted in the formation and expansion of glacial lakes. The glacier area has been decreased by $13 \%$ during 1977 to 1990 , while in other decades, it was only $7 \%$ (Bajracharya et al. 2014). Past studies in the Poiqu sub-basin shows an increase in the number of glacial lakes with area in excess of $0.02 \mathrm{~km}^{2}$ of $11 \%$ and an increase in total area of glacial lakes of $47 \%$ between 1986 and 2001 (Chen et al. 2007). Similarly, in Pumqu sub-basin, the number of glacial lakes increased by $26.6 \%$ and area increased by $26.76 \%$ between the 1970 s and 2013 (Che et al. 2014). In the Rongxer, the number increased by $86.7 \%$ and the area by $121.7 \%$ between 1975 and 2005 (Wu et al. 2012). A study in the Mt. Everest region in Nepal showed an increase in the area of glacial lakes by $13 \%$ between 1990 and 2000 and by $20 \%$ between 2000 and 2009 (Gardelle et al. 2011). Another study in the central Himalayas showed an increase in the number of glacial lakes by $10.3 \%$ and in area by $17.3 \%$ between
1990 and 2010 (Nie et al. 2013). There has been a wide range in reported growth rates by sub-basins and regions in the different study periods. The present study found a slightly lower rate of growth in area of glacial lakes than the growth rate reported in the Everest region. However, the trend of increase in the area of glacial lakes $(5.6 \%$ for the period $1990-2000$ and $7.8 \%$ for $2000-2009$ ) is similar to the findings in the Everest region (i.e., $13 \%$ for the period 1990-2000 and 20\% from 20002009) (Gardelle et al. 2011).

\subsection{Rapidly expanding glacial lakes}

The present study identified a total of 42 glacial lake with a high growth rate $(>25 \%)$ and of size $\left(>0.2 \mathrm{~km}^{2}\right)$ in the Koshi basin, while need further assessment to identify how critical they are in terms of GLOF (Figure 5). Similar results have been reported by earlier studies. For example, based on the expansion rate, area, and type of glacial lakes, 67 glacial lakes were identified by Nie et al. (2013) as rapidly-expanding glacial lakes in the central Himalayan region that need to be closely monitored in the future. Similarly, 19 glacial lakes were identified as potentially dangerous in the Pumqu sub-basin (Che et al. 2014), 16 in Rongxer sub-basin on the Chinese side (Wu et al. 2005), and 7 in the Poiqu sub-basin (Wang et al. 2015). In the Nepal part of the Koshi basin, a total of 16 potentially dangerous lakes has been reported (ICIMOD 2011). Among the glacial lakes that have been identified as potentially dangerous in past studies, some are the same as those identified in this study as rapidly growing lakes of $>0.2 \mathrm{~km}^{2}$ but many others are different. As the criteria used for the identification of potentially dangerous glacial lakes also includes the condition of the dam and association with the mother glacier (Che et al. 2014; ICIMOD 2011), such differences are expected. However, there is a need for further assessment of GLOF risk for at least these 42 glacial lakes which have high growth rate ( $>25 \%$ ) with considerable size $\left(>0.2 \mathrm{~km}^{2}\right)$.

\subsection{Temporal characteristics of the glacial lake}

In the 33 years spanning 1977 to 2010, the 129 selected glacial lakes (end moraine dammed lakes that were greater than $0.1 \mathrm{~km}^{2}$ ) in the Koshi basin 
have undergone remarkable changes in area, increasing from $42.92 \mathrm{~km}^{2}$ in 1977 , to $50.96 \mathrm{~km}^{2}$ in 1990 , to $55.70 \mathrm{~km}^{2}$ in 2000 and to $63.28 \mathrm{~km}^{2}$ in 2010. The change in total area showed a different tendency between the north and south side of Himalayas. On the north side of the Himalayas (China), the relative area change of glacial lakes was $15.75 \%$ from $1977-1990$, 9.22\% from 19902000, and $15.02 \%$ from 2000-2010, showing a decreasing and then an increasing trend. However on the south side (Nepal), the relative area change was $30.19 \%$ from $1977-1990$, $9.52 \%$ from 19902000 and $8.69 \%$ from 2000-2010, showing a declining trend for all periods. The number of stable glacial lakes showed a decreasing trend and then an increasing trend within the 33 year period. The number of stable lakes decreased from 47 in the period 1997-1990 to 35 in the period 19902000 and then increased to 48 in the period 20002010. However, the number of growing lakes decreased from 65 in the period 1977-1990 to 64 in the period 1990-2000, and then to 62 in the period 2000-2010. The total number of shrinking glacial lakes was found to be higher in the period 1990-2000 than in the other two periods, which exhibited a same decreasing trend.

The glacial lake change rate fluctuated in different period. At first the mean area growth rate of glacial lakes showed a decreasing trend and then an increasing trend. In the period 1977-1990, the mean area growth rate was $0.011 \mathrm{~km}^{2} /$ year, decreasing to $0.008 \mathrm{~km}^{2} /$ year in the period 1990 to 2000 , and again increasing to $0.012 \mathrm{~km}^{2} /$ year in the period 2000-2010. The mean length growth rate of glacial lakes maintained a consistent trend of $24.69 \mathrm{~m} /$ year in the period 1977-1990, decreased to $18.51 \mathrm{~m} /$ year in the period 19902000 , and again increased to $29.40 \mathrm{~m} /$ year in the period 2000-2010. The mean area shrink rate of glacial lakes showed a continual declining rate in the period 1977-2010. In the period 1977-1990, the mean area shrink rate was $0.003 \mathrm{~km}^{2} /$ year, decreasing to $0.002 \mathrm{~km}^{2} /$ year in the period $1990-$ 2000 , and $0.001 \mathrm{~km}^{2} /$ year in the period 20002010. The mean length shrink rate for different periods showed an increasing rate at first and then a decreasing rate: increasing from $6.52 \mathrm{~m} /$ year in the period $1977-1990$ to $8.67 \mathrm{~m} /$ year in the period 1990-2000, and decreasing to $3.90 \mathrm{~m} /$ year in the period 2000-2010.
Most of the glacial lakes in the Koshi basin have expanded, although a few have shrunk, however, the decrease rate was far less than the expansion rate. This is because increasing ablation rate induced by rising temperature has made glacier shrinkage. The retreating and melting of glacier ice increases the water supplies to the lakes, hence expanding the glacial lake area. Also, the retreating mother glaciers provides space for the glacial lakes to expand towards them. From 1977 to 2010 , the decrease rate was $0.001 \mathrm{~km}^{2} /$ year while the expansion rate was $0.008 \mathrm{~km}^{2} /$ year. With regard to length change, lake expansion on the south side of the Himalayas (Nepal) was greater than on the north side (China) by $28.45 \mathrm{~m} /$ year and $20.92 \mathrm{~m} /$ year, respectively during the period 1977-1990. However, in the other two decades, the length of expansion was higher on the north side than on the south side with an expansion rate of $19.09 \mathrm{~m} /$ year and $17.93 \mathrm{~m} /$ year during the period 1990-2000 and 34.37m/year and $24.42 \mathrm{~m} /$ year during the period 2000-2010. Over the 33 year period of the study (1977-2010), the length expansion rate on the north side was found to be almost similar to the south side (16.92 m/year on the north and $16.74 \mathrm{~m} /$ year on the south).

\section{Conclusion}

This study gives insights into the status and overall variation of glacial lakes in the Koshi basin from 1977 to 2010. According to the 33 years glacial lake inventory, the glacial lakes in the Koshi basin have changed from 1160 to 2168 in number with a total area from 94.44 to $127.61 \mathrm{~km}^{2}$ from 1977 to 2010. The majority of glacial lakes in the Koshi basin are moraine dammed lakes, followed by bedrock dammed and ice dammed lakes. Likewise, the majority of glacial lakes are of small size $\left(\leqslant 0.1 \mathrm{~km}^{2}\right)$ with an average size of $0.02 \mathrm{~km}^{2}$. Both the number and the area of glacial lakes have consistently increased since 1977, however, the decadal increase in area is higher than the increase in number in the 2000-2010. One of the characteristics of glacial lakes in the Koshi basin is that lakes, particularly those of smaller size, appear and disappear over time. It was found that 95.9\% of the glacial lakes mapped in 1977 continued to appear in the 2010 inventory. Although the total 
area of glacial lakes has been increasing, the majority of glacial lakes (57\%) showed negative growth in area between 1977 and 2010, most of which are small in size. However, large lakes (>0.2 $\mathrm{km}^{2}$ ) have been growing rapidly, contributing to the increase in area of glacial lake coverage in the basin as a whole.

To reflect the actual variation and characteristics of glacial lakes, 129 end moraine dammed glacial lakes with area more than $0.1 \mathrm{~km}^{2}$ were selected to analyse the area and length of change in glacial lakes over the 33 year study period (1977-2010). The total area of glacial lakes increased from $42.92 \mathrm{~km}^{2}$ in 1977 to $63.28 \mathrm{~km}^{2}$ in 2010. Most of the glacial lake expansion was located between $4300-5700 \mathrm{~m}$ a.s.l. on the north side of the Himalayan range (in China) and between $4300-5600 \mathrm{~m}$ a.s.l. on the south side (in Nepal). The expansion rate of glacial lakes on the south side was slightly greater than on the north side of the Himalayas from 1977 to 2010, but this relationship was not constant for the different time period.

The study identified 42 lakes that are greater than $0.2 \mathrm{~km}^{2}$ in size and with a growth rate of more than 25\% between 1977 and 2010, implying a potential risk and need to be monitored and observed continuously to derive the information on the indicated characteristics that induce GLOF. Moreover, the monitoring of glacial lakes in the field, modeling of potential outburst floods, inundation mapping, and downstream vulnerability assessment, as well as capacity building for GLOF risk management, are recommended in potential GLOF areas. Bilateral and regional cooperation between and among the countries sharing the basin is essential for monitoring and developing an early warning system for GLOF risk management in an effective manner.

\section{Reference}

Bajracharya SR, Maharjan SB, Shrestha F (2014) Glacier Status in Nepal and Decadal Change from 1980 to 2010 Based on Landsat Data. Kathmandu: ICIMOD. p 86. http://lib.icimod.org/record/29591/files/GSN-RR14-2.pdf Bajracharya SR, Shrestha B (2011a) The Status of Glaciers in the Hindu-Kush Himalayan Region. Kathmandu: ICIMOD. p 125 http://lib.icimod.org/record/9419/files/icimodthe_status_of_glaciers_in_the_hindu_kushhimalayan_region[1].p $\overline{\mathrm{df}}$

Bajracharya SR (2011b) Change in glacial environment of Everest region, Nepal. In: Proceedings of the 1oth International Symposium on High Mountain Remote Sensing Cartography. Grazer Schriften der Geographie und

\section{Acknowledgement}

This work was supported by the Cryosphere Monitoring Programme (CMP) of the International Centre for Integrated Mountain Development (ICIMOD) funded by the Norwegian Ministry of Foreign Affairs. It was also partially supported by core funds of ICIMOD contributed by the Governments of Afghanistan, Australia, Austria, Bangladesh, Bhutan, China, India, Myanmar, Nepal, Norway, Pakistan, Switzerland, and the United Kingdom; and by the Koshi Basin Programme at ICIMOD, which is supported by the Australian Government through the Sustainable Development Investment Portfolio for South Asia. The authors are grateful to ICIMOD colleagues who provided significant contributions during various phases of the studies.

\section{Open Access}

This article is licensed under a Creative Commons Attribution 4.0 International License, which permits use, sharing, adaptation, distribution and reproduction in any medium or format, as long as you give appropriate credit to the original author(s) and the source, provide a link to the Creative Commons licence, and indicate if changes were made.

The images or other third party material in this article are included in the article's Creative Commons licence, unless indicated otherwise in a credit line to the material. If material is not included in the article's Creative Commons licence and your intended use is not permitted by statutory regulation or exceeds the permitted use, you will need to obtain permission directly from the copyright holder.

To view a copy of this licence, visit http://creativecommons.org/licenses/by/4.0/.

Raumforschung, Band 45. pp 83-90.

Bajracharya SR, Mool PK (2009) Glaciers, glacial lakes and glacial lake outburst floods in the Mount Everest region, Nepal. Annals of Glaciology 50(53): 81-86. https://doi.org/10.3189/172756410790595895

Bajracharya SR, Mool PK, Shrestha BR (2008) Mapping of glacial lakes and GLOF in the Himalaya. In: Full Proceedings of the ICIMOD regional policy workshop, Kathmandu, Nepal, 18-20 September, 2006.

Bajracharya, SR, Mool PK, Shrestha BR (2007) Impact of Climate Change on Himalayan Glaciers and Glacial Lakes: Case Studies on GLOF and Associated Hazards in Nepal and Bhutan. ICIMOD, Nepal. p 133. 
Bajracharya SR, Mool PK (2005) Growth of Hazardous Glacial Lakes in Nepal. In: Proceedings of the JICA Regional Seminar on Natural Disaster Mitigation and Issues on Technology Transfer in South and Southeast Asia. Kathmandu: Department of Geology, Tri-Chandra Campus, TU. 30 September to 13 October 2004. p131-148.

Benn DI, Lehmkuhl F (2000) Mass balance and equilibriumline altitudes of glaciers in high-mountain environments. Quaternary International (65/66): 15-29.

https://doi.org/10.1016/S1040-6182(99)ooo34-8

Bhambri R, Bolch T, Chaujar RK, et al. (2011) Glacier changes in the Garhwal Himalaya, India, from 1968 to 2006 based on remote sensing. Journal of Glaciology 57(203): 543-556. https://doi.org/10.3189/002214311796905604

Bolch T, Kulkarni A, Kääb A, et al. (2012) The state and fate of Himalayan glaciers. Science 336: 310-314.

https://doi.org/10.1126/science.1215828

Bolch T, Menounos B, Wheate R (2010) Landsat based inventory of glaciers in western Canada, 1985-2005. Remote Sensing of Environment 114(1): 127-137.

https://doi.org/10.1016/j.rse.2009.08.015

Byers AC, Mckinney DC, Somos_Valenzuela MA, et al. (2013) Glacial lakes of the Hinku and Hongu valleys, Makalu Barun National Park and Buffer Zone, Nepal. Natural Hazards 69(1): 115-139. https://doi.org/10.1007/s11069-013-0689-8

Campbell JG (2005) Inventory of glaciers and glacial lake and the identification of potential glacial lake outburst floods (GLOFs) affected by global warming in the mountains of India, Pakistan and China/Tibet Autonomous Region. Final report submitted to APN, 2004-03 CMY, Kathmandu, Nepal: ICIMOD \& APN. p 39

Che T, Xiao L, Liou YA (2014) Changes in glaciers and glacial lakes and the identification of dangerous glacial lakes in the Pumqu River Basin, Xizang (Tibet). Advances in Meteorology. https://doi.org/10.1155/2014/903709

Chen NS, Hu GS, Deng W et al. (2013) On the water hazards in the trans-boundary Koshi River basin. Natural Hazards Earth System Science 13: 795-808.

https://doi.org/10.5194/nhess-13-795-2013

Chen X, Cui P, Li Y, et al. (2007) Changes in glacial lakes and glaciers of post-1986 in the Poiqu River basin, Nyalam, Xizang (Tibet). Geomorphology 88(3-4): 298-311. https://doi.org/10.1016/j.geomorph.2006.11.012

Frey H, Huggel C, Paul F, et al. (2010) Automated detection of glacier lakes based on remote sensing in view of assessing associated hazard potentials, In: Kaufmann V and Sulzer W (eds.), Proceedings of the 10th International Symposium on High Mountain Remote Sensing Cartography. Grazer Schriften der Geographie und Raumforschung, Band 45. pp 261-272.

Gardelle J, Arnaud Y, Berthier E (2011) Contrasted evolution of glacial lakes along the Hindu Kush Himalaya mountain range between 1990 and 2009. Global and Planetary Change 75(1-2): 47-55. https://doi.org/10.1016/j.gloplacha.2010.10.003

Granshaw FD, Fountain AG (2006) Glacier change (1958-1998) in the North Cascades National Park Complex, Washington, USA. Journal of Glaciology 52(177): 251-256.

https://doi.org/10.3189/172756506781828782

Huggel C, Kääb A, Haeberli W, et al. (2002) Remote sensing based assessment of hazards from glacier lake outbursts: a case study in the Swiss Alps. Canadian Geotechnical Journal 39(2): 316-330. https://doi.org/10.1139/to1-099

ICIMOD (2011) Glacial lakes and glacial lake outburst floods in Nepal. Kathmandu: ICIMOD.

Ives JD (1986) Glacial lake outburst floods and risk engineering in the Himalaya: A review of the Langmoche disaster, Khumbu Himal, 4 August 1985. Occasional Paper 5. Kathmandu, Nepal: ICIMOD

Khanal NR, Hu JM, Mool P (2015a) Glacial Lake outburst flood risk in the Poiqu/Bhote Koshi/Sun Koshi river basin in the Central Himalayas. Mountain Research and Development 35(4): 351-364 https://doi.org/10.1659/MRD-JOURNAL-D-15-00009

Khanal NR, Mool PK, Shrestha AB, et al. (2015b) A comprehensive approach and methods for glacial lake outburst flood risk assessment, with examples from Nepal and the transboundary area. International Journal of Water Resources Development 31(2): 219-237. https://doi.org/10.1080/07900627.2014.994116

Khanal NR, Acharya C (2008) GLOF Risk Assessment in Bhotekoshi/Sunkoshi Basin. Unpublished technical report submitted to the International Centre for Integrated Mountain Development, Kathmandu, Nepal, available from corresponding author of this article.

Li JL, Sheng YW (2012) An automated scheme for glacial lake dynamics mapping using Landsat imagery and digital elevation models: a case study in the Himalayas. International
Journal of Remote Sensing 33: 5194-5213.

https://doi.org/10.1080/01431161.2012.657370

Lamsal D, Sawagaki T, Watanabe T, et al. (2014) Assessment of glacial lake development and prospects of outburst susceptibility: Chamlang South Glacier, eastern Nepal Himalaya. Geomatics, Natural Hazards and Risk 7(1):1-21. https://doi.org/10.1080/19475705.2014.931306

LIGG [Lanzhou Institute of Glaciology, Chinese Academy of Science], WECS [Water and Energy Commission Secretariat, Nepal], NEA [Nepal Electricity Authority] (1988) Report on first expedition to glaciers and glacier lakes in the Pumqu (Arun) and Poiqu (Bhote-Sun Kosi) river basins, Xizang (Tibet), China: Sino-Nepalese investigation of glacier lake outburst floods in the Himalayas. Beijing, China: Science Press.

Mool P, Bajracharya SR, Joshi SP (2001) Inventory of glaciers, glacial lakes, and glacial lake outburst floods: Monitoring and early warning systems in the Hindu Kush-Himalayan region Nepal. Kathmandu: ICIMOD.

Nie Y, Liu Q, Liu S (2013) Glacial lake expansion in the central Himalayas by Landsat images, 1990-2010. PloS One 8(12): e83973. https://doi.org/10.1371/journal.pone.0083973

Neupane N, Murthy MSR, Rasul G, et al. (2013) Integrated biophysical and socioeconomic socioeconomics model for adaptation to climate change for agriculture and water in the Koshi Basin. In Handbook of Climate Change Adaptation. Springer Berlin Heidelberg. pp 1835-1859.

https://doi.org/10.1007/978-3-642-40455-9_77-1

Raj KBG, Remya SN, Kumar KV (2013) Remote sensing-based hazard assessment of glacial lakes in Sikkim Himalaya. Current Science (Bangalore) 104(3): 359-364.

https://doi.org/10.1080/19475705.2012.707153

Reynolds JM (2000) On the formation of supraglacial lakes on debris-covered glaciers. Debris covered glaciers (Proceedings of a workshop held at Seattle, Washington, USA, September 2000). IAHS Publication no. 264. pp 153-161.

Richardson SD, Reynolds JM (2000) An overview of glacial hazards in the Himalayas. Quaternary International $(65 / 66)$ : 31-47. https://doi.org/10.1016/S1040-6182(99)00035-X

Vuichard D, Zimmermann M (1986) The Langmoche flash-flood, Khumbu Himal, Nepal. Mountain Research and Development 6(1): 90-94. https://doi.org/10.2307/3673345

Wang W, Xiang Y, Gao Y, et al. (2015) Rapid expansion of glacial lakes caused by climate and glacier retreat in the Central Himalayas. Hydrological Processes 29(6): 859-874. https://doi.org/10.1002/hyp.10199

Wang X, Liu S, Guo W, et al. (2012) Using remote sensing data to quantify changes in glacial lakes in the Chinese Himalaya. Mountain Research and Development 32(2): 203-212. https://doi.org/10.1659/MRD-JOURNAL-D-11-OO044.1

Watanabe T, Ives JD, Hammond JE (1994) Rapid growth of a glacial lake in Khumbu Himal, Himalaya: Prospects for a catastrophic flood. Mountain Research and Development 14(4): 329-340. https://doi.org/10.2307/3673729

WECS (1987) Preliminary study of glacier lake outburst floods (GLOFs) in the Nepal Himalaya. Unpublished technical report of Water and Energy Commission Secretariat, Kathmandu, Nepal, available from corresponding author of this article. $\mathrm{p} 495$.

Wu L, Che T, Jin R, et al. (2005) Inventory of glaciers, glacial lakes and the identification of potential glacial lake outburst floods (GLOFs) affected by global warming in the mountains of Himalayan region: Pumqu, Rongxer, Poiqu, Zangbuqin, Jilongcangbu, Majiacangbu, Daoliqu, and Jiazhagangge basins, Tibet Autonomous Region, People's Republic of China. Project report, with database on CD-ROM. Kathmandu: ICIMOD and APN. p 117.

Wu S, Yao Z, Huang H, et al. (2012) Responses of glaciers and glacial lakes to climate variation between 1973 and 2005 in the Rongxer basin of Tibet, China and Nepal. Regional Environment Change 12(4): 887-898.

https://doi.org/10.1007/ s10113-012-0302-9

$\mathrm{Xu}$ D (1988) Characteristics of debris flow caused by outburst of glacial lake in Boqu river, Xizang, China, 1981. GeoJournal 17(4): 569-580. https://doi.org/10.1007/BFo0209443

Yamada T, Sharma CK (1993) Glacier Lakes and outburst floods in the Nepal Himalaya. In Young GJ (ed.), Snow and Glacier Hydrology (Proceedings of the Kathmandu Symposium, Nov. 1992). IAHS Publication no. 218. pp 319-330.

Yao T et al (2010) Glacial distribution and mass balance in the Yarlung Zangbo River and its influence on lakes. Chinese Science Bulletin 55(20): 2072-2078. https://doi.org/10.1007/s11434-010-3213-5

Zhang G, Yao T, Xie H, et al. (2015). An inventory of glacial lakes in the Third Pole region and their changes in response to global warming. Global and Planetary Change 131: 148-157. https://doi.org/10.1016/j.gloplacha.2015.05.01 